\title{
ISSUES OF EFFICIENCY FOR PUBLIC-PRIVATE PARTNERSHIPS IN THE WATER SECTOR
}

\author{
Simona Frone \\ Institute of National Economy at the Romanian Academy \\ frone.simona@gmail.com \\ Dumitru Florin Frone \\ University of Agricultural Sciences and Veterinary Medicine Bucharest \\ ffrone@hotmail.com
}

\begin{abstract}
The water resources are critical for the economic development in a country or region, since the pollution and depletion of the waters are raising concerns for the environmental and economic efficiency of their management. This outlook calls for analysis on economic and financial issues and risks associated with specific investment projects in water supply and sanitation infrastructure WSS. In previous research outcomes we have shown successful models of PublicPrivate Partnerships (PPP) used to manage and mitigate the risks and improve performance in providing the public services of Water Supply and Sanitation (WSS). The main objective of this paper is to reiterate the PPP as an efficient business model for the water sector, by employing several methodologies: literature review, case studies, performance indicators, analysis and synthesis. Some features and experiences of PPP in the water sector are resumed and analysed, considering recent developments and leading to conclusions and recommendations on their opportunity and efficiency in Romania.
\end{abstract}

\section{Keywords}

efficiency; Public Private Partnership (PPP); economic risk; Water Supply and Sanitation (WSS); concession

\section{JEL Classification}

H44; L95

\section{Introduction}

As analysed and mentioned in previous research papers in the last about 15 years important trends have occurred within the water sector of the European Union, mainly driven by the European Water Framework Directive 2000/60/EC.

Since having dealt mostly with water demand management and regionalization of water utilities, in order to determine the most efficient path for sustainable development and efficient water management, there is an urge to consider another trend: privatization of the water companies' management through Public-Private Partnerships (PPP) and creation of a competitive market in the water supply and sanitation (WSS) industry.

Sustainable development depends also on managing the costs of service provision using existing infrastructure along with additional investments in new water infrastructure and rehabilitation, both physical and institutional.

Therefore, the water/wastewater sector is still undergoing important institutional, economic and technological reforms, aiming at ensuring the financial as well as environmental sustainability of the water and wastewater utilities and services (Frone $\&$ Frone, 2012b). 
The process of regionalisation and aggregation of the Romanian water sector was a strategic move, being expected to create, besides economies of scale, also a large enough demand base for the Regional WSS operators to become attractive for private sector participation (Frone, 2012).

The paper will highlight some specific features of the water sector and the implications on suitable forms of PPP designed to increase the efficiency of the WSS companies and to allow for a more equitable risk sharing between the public and the private sector.

\section{Background concepts}

There are quite difficult economic and political choices for the sustainable management of the urban water sector at present.

The importance of the water supply and sanitation (WSS) networks and services has long been proven as an essential public good for socio-economic development, since:

- The provision of water and sanitation services has undoubtedly reduced disease and has yielded health benefits.

- The cheap access to water has also encouraged a variety of other uses from agricultural to architectural developments.

\subsection{Water as a social and economic good}

However, the water sector is marked by a long history of under-pricing, and opposition to full cost pricing for ethical and social reasons. As analysed in (Frone, 2012) water is an economic good, as well as a social good. In view of a sustainable development, it is important to view water allocation as a means of meeting social goals of equity, poverty alleviation and safeguarding health.

The social and political factors and the public character of water have contributed in the past to the reluctance of governments to acknowledge water as a finite natural resource and an economic good.

Water is, however, from the economic analysis viewpoint, a commodity that needs a market price reflecting the cost of provision and its true value to society. Besides, as claimed in previous research papers, sustainable water management calls for an integrated approach to the supply and demand of water. Therefore, modern water industry and infrastructure deals both with:

- The supply side, consisting in the collection, treatment, transport, storage and distribution of fresh water;

- The demand side, by collecting, transporting and treating the used (waste) water.

Still, due to the incapacity or the unwillingness to acknowledge water as a finite natural resource and an economic good - a commodity that needs a market price reflecting the cost of provision and its true value to society (Frone, 2012), public water systems are often operated inefficiently and services are unreliable, lacking coverage, regular maintenance and good design.

Currently more than 1 bn people worldwide still lack access to safe drinking water and up to 2 bn people do not have access to basic sanitation facilities. Improving the delivery of urban water and waste water services is still a critical need for many developing countries and economies in transition.

Our country Romania, although a Member state of the European Union, still faces challenges and issues in increasing the access of the rural population to WSS networks and services. Currently in Romania only about $60 \%$ of the total population has access to full public water supply, sewerage and sanitation, due to the 
underdevelopment of water/wastewater infrastructure or to low rates of connection (Frone \& Frone, 2012).

Therefore, as we shall argue in this paper, in the long run, regional and local governments (public authorities) should consider, for developing and delivering WSS infrastructure and utilities the potential involvement of some private sector partners in dedicated partnership projects.

The main grounds and reasons for public-private partnerships (PPPs) in the water sector are:

- Improving the delivery and coverage of WSS utilities is a critical need for the emerging economies and all the EU member states (including Romania), in order to be able to comply with the Water Directives;

- In the European Union about USD 75bn per year are currently spent on water and waste water services, and capital investment is predicted to increase by $7 \%$ a year for the foreseeable future;

- Public water systems are often operated inefficiently: lack of coverage, of regular maintenance and of good design;

- Private WSS companies might be able to offer increased access to their private investment funds

- The improved and innovative management systems, technologies and techniques.

\subsection{Forms and features of Public-Private Partnerships in the water sector}

After having acknowledged some features of the water utilities, and the fact that there is a need to involve the private sector capital and management capacity, the PPP in the water sector, should not be misunderstood as full privatization, with the management and ownership of water infrastructure transferred to the private sector.

In a general definition, the Public-Private Partnerships (PPPs) refer to any form of agreement (partnership) between public and private parties.

Hence without passing all the ownership and operations to the private operator, there is still a quite wide range of approaches for involving the private sector in improving the performance of water and sanitation systems.

Some options keep the operations (and ownership) in public hands, but involve the private sector in the design and construction of the infrastructure. Other options involve private actors in the management, operation and/or the financing of assets. Accordingly, they involve different degrees of private and public sector responsibilities for service delivery.

The main features of the PPPs in the water sector are:

o Cooperation between a public partner and a private partner involving a longterm relationship;

- The funding of the projects mostly done by private partners;

$\circ$ The public entity is focused on the objectives to be achieved in the term of public interest and is responsible for monitoring the project, for the quality of the provided services and the pricing policy;

o The private partner is usually responsible for the stages in the project like design, completion, implementation and funding;

○ The risk management is done through risk sharing between partners, so that some of the main risks are being transferred from the public entity to the private partner.

There are also several forms of the PPPs in the water sector, created and designed to respond to the main problems of water supply and sanitation networks development 
or to improve the operational economic and/or environmental efficiency of the existing water utilities.

As may be noticed in Table 1, there are some common forms of Public-Private Partnerships in the water sector, more or less specially designed to meet some specific development or efficiency objectives. Also analysed in table 1, according to the main objective they are designed for, the authorities would probably choose different options of PPP.

There are some forms of PPP mainly used to develop access to WSS services and coverage, such as: the mixed-ownership (joint-venture) company in which a private investor takes a minority share in a water company with full management responsibility vested in the private partner; the concession (for 20-30 years), under which the private operator is responsible for running the entire system. Investment is mostly or fully financed and carried out by the private operator.

Table 1 Objectives and specific forms of PPPs in the water sector

\begin{tabular}{|c|c|c|c|}
\hline \multirow[b]{2}{*}{$\begin{array}{l}\text { Forms of PPPs in } \\
\text { the water sector }\end{array}$} & \multirow[b]{2}{*}{ Specific PPP options } & \multicolumn{2}{|c|}{ Objectives of the PPPs in the water sector } \\
\hline & & $\begin{array}{c}\text { Developing access to } \\
\text { WSS coverage and } \\
\text { services }\end{array}$ & $\begin{array}{l}\text { Improving } \\
\text { efficiency }\end{array}$ \\
\hline \multirow{2}{*}{ CONCESSIONS } & $\begin{array}{l}\text { The mixed-ownership } \\
\text { (joint-venture) }\end{array}$ & $* * *$ & $*$ \\
\hline & $\begin{array}{l}\text { The concession } \\
\text { (for 20-30 years) }\end{array}$ & $* * *$ & $* *$ \\
\hline \multirow{2}{*}{ CONTRACTS } & $\begin{array}{l}\text { The management } \\
\text { contract (for } 4-7 \text { years) }\end{array}$ & $*$ & $* * *$ \\
\hline & $\begin{array}{l}\text { The lease contract } \\
\text { (for } 10-15 \text { years) }\end{array}$ & $* *$ & $* * *$ \\
\hline
\end{tabular}

Legend: $* * *=$ very effective; $* *=$ effective; $*=$ less effective

Source: Own qualitative analysis

On the other hand, there are other forms of PPP designed and used especially or only to improve economic efficiency, mainly some limited time contracts, such as: the management contract (for 4-7 years), under which the private operator is only responsible for running the system, in exchange for a fee that is to some extent performance-related; the lease contract (for 10-15 years), under which assets are leased to the private operator who receives a share of revenues.

Nevertheless, due to the water sector being one of natural local monopolies, a strong regulatory role is required to ensure that performance standards are met and the interests of consumers protected. Local authorities or governments retain final responsibility for setting and enforcing performance standards.

Therefore, in all of these options or forms, the public authority remains responsible for overseeing the activity and ultimately ensuring that public needs are met (OECD, 2003).

\section{Challenges and obstacles of developing efficient Public-Private Partnerships in the Water Sector}

In some countries, Public-Private Partnerships in the water sector have existed for more than a century. Public-Private Partnerships (PPP) in the urban water sector mostly take the form of lease or concession contracts, where a public authority retains the ownership of the system and the private sector manages and operates the services. 
In its Green Paper on PPPs, the European Commission recognised that the following elements normally characterise a PPP (COM (2004)327):

-The relatively long duration of the relationship, involving cooperation between the public partner and the private partner on different aspects of a planned project;

-The method of funding the project, in part from the private sector, sometimes by means of complex arrangements between the various players;

-The important role of the economic operator, who participates at different stages in the project (design, completion, implementation, funding);

-The distribution of risks between the public partner and the private partner, to whom the risks generally borne by the public sector are transferred.

As may be noticed from a previous study (Frone \& Frone, 2013) all kind of countries (developing, middle income, advanced, even socialist national economies), from all over the world, have involved Public Private Partnerships in providing their water supply and sanitation networks and services. This is a proof that PPPs can provide solutions to communities faced with the need to improve critical infrastructure or find cost efficiencies to help fund necessary projects.

Nevertheless, despite the significant expansion of Public-Private-Partnerships in the urban water sector in recent years, it is estimated that still only $3 \%$ of the population in poor or emerging countries is provided with drinking water through private operators.

There are some specificities of the WSS systems that have a strong impact on the economic and financial features of the PPP in the water sector. Due to these features, private operators are particularly sensitive to the quality of the investment climate and the level of risk, which is an important obstacle to Public-Private Partnerships in many regions of the world:

- Networked water systems have extremely high capital costs;

- Urban water services are a business with relatively low rates of return on investment, so it is essential that revenue streams are as secure as possible;

For instance, as analysed in (Platon et al., 2014), the economic and financial risks of the WSS activity can be divided into two categories:

a) financial risks (investment related), which is the set of risks associated with investment in new infrastructure of water and wastewater: expansion of a distribution network, the creation and development of new sources of drinking water, or the construction of a new water wastewater treatment;

b) economic risks of exploitation, which is the set of risks associated with the operation and maintenance of a water supply and sewage-sanitation service.

The economic risks of the WSS projects are determined by the uncertainty of economic development, namely of the sector market. These most significant economic risks in Romania are: the commercial risks of non-payment, related to the consumer demand (i.e. the consumers reaction to increasing WSS tariffs), the risk of competition (determined by quasi - free access of rural population to water from common wells and own boreholes); the risk of inflation, the contractual risk, the legal and regulatory risk (Frone \& Frone, 2015).

\subsection{Risk sharing for increased efficiency}

Considering the specific risks of the water sector and the financial challenges brought by the recent global economic crisis, an important issue of efficiency is the selection or development of the right model of PPP arrangement.

For instance, as according to (OECD-World Bank, 2002), before the global crisis, there was a dominance of concession contracts (more than $82 \%$ of cumulated investment 1990-2000), where the objective is (see table 1) to increase the access to WSS services, but the private operator is responsible for management of operations, 
maintenance and investment, and hence exposed to a large array of risks, in conjunction with an inappropriate allocation of risks between stakeholders.

Due to the fact that many Public-Private Partnerships in the water sector were designed in a way that required the private operator to bear the political, regulatory and currency exchange risks in addition to all operational and investment related risks, the global economic crisis (2008-2012) has brought recognition that this might not be the most appropriate way of allocating these risks, since many risks are not under the control of private operators.

In figure 1, we represent in a risk matrix, the mechanisms of risk sharing for each of the main 4 types of PPP models for the WSS services; as indicated graphically by the arrow, the degree of private responsibility and risk taking increases from left to the right.

\begin{tabular}{|l|l|l|l|l|}
\hline \multicolumn{5}{|c|}{ Increased private sector responsability and riskin the PPP } \\
\hline Risk & IManagement contract & II Affermage lease & III Joint-renture & IV Concession \\
\hline D\&C & Public & Publicpnivate & Public \& private & Private \\
\hline O\&M & Private & Private & Public \& private & Private \\
\hline Compliance & Publicpnivate & Publicprivate & Public \& private & Private \\
\hline Commercial & Public & Private & Public \& private & Publicprivate \\
\hline Financial & Public & Public & Public \& private & Private \\
\hline Transaction & Publicprivate & Pnivate & Private & Private \\
\hline Regulation and legal & Private & Private & Public \& private & Private \\
\hline
\end{tabular}

Source: $0 \mathrm{wn}$ analysis and appraisal, mainly based on researched references

Figure 1 Risk matrix (risk sharing mechanisms) of the main PPP models in the WSS sector

From this viewpoint, the standard models of the public-private partnership in the water supply and sanitation sector are defined by a particular mechanism of the responsibilities and risks allocation (Frone \& Frone, 2013):

PPP type I: the management contract

Under a management contract the operator fills key management positions in the water company with appropriately skilled staff. The publicly owned water company continues to be accountable for other responsibilities, such as undertaking new investment. In this arrangement, the private sector partner will provide O\&M and/or capital programme management services and receive an annual fee from the public partner. The revenue collection function is usually retained in the public sector and the scope and mechanism of risks transfer is limited, but performance and efficiency generally improves.

PPP type II: affermage-leases

Under an affermage-lease, responsibility for operating and maintaining existing assets, plus commercial and management responsibilities, pass to the private operator. The public contracting authority usually retains responsibility for new investment. Here, the risk transferred from the contracting authority to the operator is usually quite significant, but the mechanism of risk transfer depends on the details of the contract and, in particular, the way the operator's remuneration is determined: under an affermage, the tariff adjustment rules that matter most are those applying to the operator's tariff (or affermage fee); under a lease, the operator gets the customer tariff minus a lease payment, so the tariff adjustment rules that matter most are those that 
apply to the customer tariff. There may be thus a raise in the efficiency of water systems operations.

PPP type III: joint-ventures

In this type of PPP, the public-private partnership is more intimate and integrated, since the public and private sector form a joint venture to provide water and wastewater services to the customer. It is a good practice for the public sector to inject the water infrastructure assets and the private sector partner to contribute with the capital, to form a joint venture company.

This is potentially the most complicated but is also an increasingly modern and popular model favoured by the different stakeholders. The joint venture model permits the sharing of risks in the form of profit-and-loss sharing. This allows the redistribution of savings and potential benefits in a project between the public and private partner, a provision which is usually conspicuously missing in PPP projects. The public sector will have to retain a certain degree of risks in areas like O\&M, revenue collection and financing, compliance (Figure 1).

PPP type IV: concessions

Under a concession the operator assumes full responsibility and exclusive right to operate, maintain and carry out investment in a public utility and the risk transferred from the contracting authority to the operator is usually substantial, but depends particularly on the rules for adjusting the customer tariff.

\subsection{Good practice case-study of PPP in the Water Sector: APA NOVA Bucharest}

As a handy example, we are able to cite the water and sewer system of Bucharest (capital of Romania, population of 2.3 million), privatized in 2000 through a 25 -year concession to the French company Veolia generating the Apa Nova PPP for WSS.

It is analysed and specified in (IFC World Bank Group, 2013) that before the PPP Apa Nova, the municipality of Bucharest was facing numerous problems in meeting the city's water and sanitation needs. Because of leaks in the distribution network and waste, water losses were nearly 50 percent high, which together with an inadequate metering system resulted in low revenues for the municipality.

In addition, some larger investments in sewerage, water storage and quality improvements were also required to meet EU standards. Furthermore, the complicated ownership structure of water infrastructure assets resulted in a lack of accountability and of incentives to improve efficiency; the low tariffs meant that insufficient funds were available to invest in the necessary improvements.

For choosing the best form of PPP, the main government's objectives were:

- to bring about efficiency gains, so that consumer service levels could improve with minimum tariff increases;

- to transfer most of the investment responsibilities to the private sector making it as self-sufficient as possible;

- to still avoid the dangers of a private monopoly.

Based on review, the consultant (IFC) recommended a long-term concession whereby the private operator would be responsible for managing water and sanitation services and for all capital investments.

The municipality would, however, retain ownership of the assets. Hence, the Bucharest Municipality assigned the rights and obligations to manage the public WSS services and related public assets to the company Apa Nova Bucureşti, on the company's own risk and expense, in exchange for a fee payment (royalty).

As stated in a dedicated presentation by the Bucharest Municipality (2015), the concession contract was awarded in 2000 (for 25 years), following a competitive 
international tendering procedure. The bidding was based on a single criterion: the lowest tariff. Apa Nova Bucharest (Veolia Water Group) won the tender because it offered the lowest combined water and wastewater tariff (calculated as the average of 7 tariffs proposed for specific time periods of the concession).

Other features of the Apa Nova concession contract PPP are:

- The concession contract is customer-oriented, with clear quantitative and qualitative objectives (Levels of Services) for the Concessionaire, with no imposition of obligatory investments (exception is Crivina Water Production Plant $-3 \mathrm{~m}^{3} / \mathrm{s}$ ), monitored by the Municipality of Bucharest through the Municipal Authority of Public Services Regulation;

- The concessionaire is remunerated with a strictly controlled tariff by the National Regulatory Authority for Public Services (ANRSC) and the Municipal Authority of Public Services Regulation (AMRSP).

- The concessionaire may undergo serious financial consequences if it does not achieve the set of 24 technical and commercial Levels of Services (LoS) as provided for in the Contract (1,5 M€ contractual penalty per each LoS not complied with).

Nevertheless, an issue of economic efficiency is the price (tariff) elasticity of water demand, which is quite high in Romania (Frone Simona, Frone Dumitru Florin, 2012a).

Other previous analyses have identified from a qualitative risk analysis, the outcome that the most important economic risk of WSS projects in Romania is the commercial risk, i.e. the risk of falling demand and thus the risk of non-payment of charges for the water and wastewater services, because of the high rates and low affordability of the population, especially in the rural areas (Platon et al., 2014)

Therefore, to reduce the risk of low water demand, the Bucharest WSS concession contract foresaw the possibility to increase tariffs beyond the contractually foreseen increases, if total water use was more than five per cent below water use in the previous year (Apa Nova, 2012).

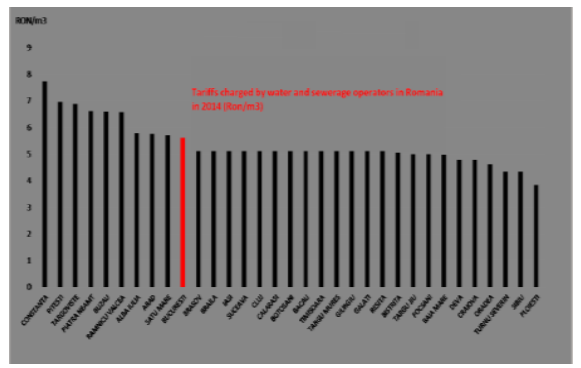

Figure 2 Comparison of the tariffs charged by the WSS operators in Romania in $2014\left(\mathrm{RON} / \mathrm{m}^{3}\right)$

Source: Report of (Bucharest Municipality, 2015)

However, an interesting conclusion of the report (Bucharest Municipality, 2015) was that Apa Nova has managed to improve service more than average while keeping tariffs relatively low, without receiving any public subsidy.

As may be noticed in Figure 2, the tariffs charged for the water supply and sewerage services in Bucharest by the Apa Nova were not the highest in Romania, in 2014 (the $10^{\text {th }}$ position out of the 33 WSS companies operating at the time).

The solution lies mainly in the ability of the concession to increase efficiency. The efficiency gains "enable Apa Nova to generate the operational cash-flow needed to cover loans and ensure the return on capital invested." 
A key accomplishment for economic efficiency was that Apa Nova Bucuresti has reduced non-revenue water (including leakage and commercial losses due to underbilling, theft etc.) from 350 cubic meters per kilometer of network per day in 2002 to 176 cubic meters/kilometer/day in 2007.

Also, the water quality has improved in Bucharest, due to the PPP: in 2000, 69 percent of samples complied with the standard for residual free chlorine; in 2010, 100 percent of water samples met or exceeded Romanian and E.U. quality standards. The overall customer satisfaction had increased from 46 percent in 2002 to 75 percent in 2009.

The water consumption in Bucharest decreased from total consumption of 516 liters per capita per day in 1999 to 225 liters per person per day in 2010, and is decreasing at a compound annual rate of 8 percent due to reduced leakage.

Therefore, not only in our view but in many reports, the Apa Nova Bucharest PPP for municipal water services is to be praised for being considered very successful since „under the private operator the utility: has raised service quality above Romanian standards and toward Western European levels; by 2008 efficiency gains had produced cost savings of US\$34million. The concessionaire has financed US\$259 million in investment, without public subsidy, while keeping tariffs well below the Romanian average" (World Bank, 2013).

\subsection{The scope of efficient PPPs in the Water Sector}

Even when the obstacles for PPP in the water sector are overcome and there are successful stories of good-practice like the one of Bucharest Apa Nova, it must be recognized, however, that Public-Private Partnerships are not always the panacea that some might expect. Due to the specificities of the sector, the PPP involving international private sector operators, although potentially efficient and desired, cannot solve all the problems in the water sector, nor can be applied everywhere.

It should be first acknowledged that the private sector will only operate where certain profitability requirements can be met, which considerably limits the scope for the water sector Public-Private Partnerships.

Also, for some reasons mentioned in (Platon et al., 2014) regarding the financial risks, major investments in the framework of water Public-Private Partnerships is likely to focus on developed and emerging market economies where the framework conditions for foreign investors are most favourable.

In the previous century, close to $100 \%$ of the value of Public-Private Partnerships projects has been realized in high and middle income countries, leaving most Least Developed Countries uncovered.

Although water utilities are now prone to continuous development and innovation, there is a limited number of international water operators, so their human and financial capacities allow for the management of only a small number of projects. The three largest private operators accounted for more than $50 \%$ of the global market in the last 15 years.

Due to the low propensity to pay for WSS services and the tariff risk (Frone \& Frone, 2012a) the rural areas as well as small and medium cities in Romania and in other developing countries are not or only rarely on the shortlist of international private operators.

Instead, the PPPs in the water sector will focus on urban areas which are likely to yield the most substantial revenue flows and offer the best opportunities to achieve significant economies of scale: usually large cities with a population of 500.000 or more (see above the case of Bucharest, as the capital of Romania, with more than 2 million inhabitants). 
Hence it may be stated that the potential area of operation of international private operators is limited. Still opportunities for the involvement of new entrants into the urban WSS market exist by a mobilization of new actors from the private sector in developing countries, as well as of some smaller water companies which may help to enlarge the scope for efficient PPP in the future.

\section{Conclusions and recommendations}

In Romania the most important economic risk of WSS projects is a commercial risk, i.e. the risk of falling demand and thus the risk of non-payment of charges for the water and wastewater services, because of the high rates and low affordability of the population, especially in the rural areas. This economic risk is really jeopardizing the efficiency of the water companies and normally does not foster the creation and development of some forms of PPPs for the much required and needed development of the water supply and sewerage networks and services in Romania.

However, in developed and higher-income areas such as the capital city Bucharest, the Apa Nova PPP has worked efficiently as according to an independent evaluation study (done at the request of International Finance Corporation) showing that:

"In Bucharest, the PPP concession has clearly improved water and wastewater services. ... The main success drivers were: a committed public authority; a committed and expert advisory team; a well-prepared, high quality, and transparent transaction process; an unusually thoughtful and innovative contract design; welldesigned and implemented contract monitoring and disputing resolution arrangements." (CASTALIA STRATEGIC advisors, cited in the Bucharest Municipality report, 2015) The investment costs of the Apa Nova for developing the WSS services were also lower, due to the strong features of the private-public partnership PPP (better capital endowment and equity).

In conclusion and according to the research, PPP agreements are resourceful and should be used more widely in the financing and development of WSS infrastructure and services, in Romania and in other EU states.

For implementing efficient PPP in the water sector of Romania, the outlook is good since there is a proof of success by Apa Nova in Bucharest. Besides, as stated already in (Frone \& Frone, 2013) the Sustainable Development Strategy of Water Supply and Sanitation Public Services- Romania 2025 supports the involvement of private capital in large investments, especially through PPP arrangements required to achieve the major construction and expansion of treatment plants and wastewater.

\section{References}

Apa Nova (2012), The concession contract, retrieved on May 14, 2013.

Bucharest Municipality (2015), Improving the Efficiency of the Public Water Service through concession in Bucharest, the capital city of Romania, CAPITAL SUMMIT 2015, Belgrade, 22-24th April 2015.

Commission of the European Communities (2004), Green Paper on Public Private Partnerships and Community Law on Public Contracts and Concessions, COM (2004) 327.

Frone, S., Frone, D.F. (2015), Emerging markets Queries in Finance and Business. Economic risk to a regional water supply and sanitation project in Romania. Procedia Economics and Finance, 32, 550-557.

Frone, S., Frone, D.F. (2013), Public-Private Partnerships as Mechanisms for Risk Management in the Water Sector. Scientific Papers. Series "Management, 
Economic Engineering in Agriculture and rural development”, Vol. 13 Issue 3, 103-110.

Frone, S., Frone, D.F. (2012a), Sustainable Water Pricing and Demand Management Issues in Romania, Ovidius University Annals, Economic Sciences Series, Vol. 0(1), 937-942.

Frone, S., Frone, D.F. (2012b), Factors and Trends of Economic Efficiency in the Water/Wastewater Sector, Procedia Economics and Finance, Vol. 3, Elsevier.

International Financial Corporation, World Bank Group (2013), Public-Private Partnership Impact Stories. Romania: Bucharest Water and Sanitation, IFC WB Group 2013.

OECD/World Bank (2002), Private sector participation in municipal water services in Central and Eastern Europe and Central Asia, Conference proceedings, 10-11 April 2002, Paris.

Organisation for Economic Co-operation and Development (2003), Public-Private Partnerships in the Urban Water Sector, OECD Observer, April 2003.

Platon, V. et al (2014), Financial and economic risks to public projects, Procedia Economics and Finance, 8, 204-210.

World Bank (2011), Water in Bucharest: A Utility's Efficiency Gains under a Concession, February 2011, Viewpoint Note No. 326, by David Earhardt, Melissa Rekas and Martina Tonizz, retrieved on May 14, 2012. 